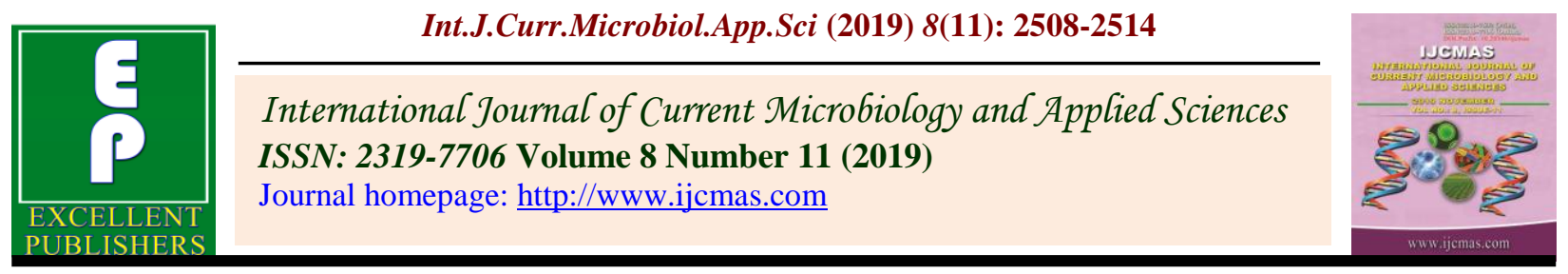

Original Research Article

https://doi.org/10.20546/ijcmas.2019.811.289

\title{
Association between Income Generation and Socio Economic Profile of the Tribal Farmers of Nanded District, India
}

\author{
V.K. Gogi Reddy", J.V. Ekale, M.V. Kulakarni and R.G. Nair \\ Department of Extension Education, Vasantrao Naik Marathwada Krishi Vidyapeeth, \\ Parbhani 431402 (M.S.), India \\ *Corresponding author
}

\begin{tabular}{|l|}
\hline Key w or d s \\
Socio economic \\
profile, Tribal \\
farmers and income \\
generation
\end{tabular}

A B S T R A C T

The present study was conducted in Nanded district of Marathwada region of Maharashtra state during the year 2018-2019. The main aim of the study is to find out association between Income generation and socio economic profile of the tribal farmers with respect to their sustainable livelihoods. For the study following variables are selected age, education, farm size, farming experience, training received, risk orientation, religious belief, achievement motivation, extension contact, mass media exposure, ethnocentrism and Income generation. From the study, it can be observed that there was a positive and significant relationship between income generation of sustainable livelihoods of farmers and the variables farm size, training received, achievement motivation, extension contact and mass media exposure. Calculated ' $r$ ' values between age, farming experience ethnocentrism and the income generation of sustainable livelihoods of farmers have negative and significant relationship. On the other hand education, risk orientation and, religious belief has no significant relationship with the income generation of sustainable livelihoods of tribal farmers.

\section{Introduction}

Since the introduction of economic reforms in early nineties, there has been greater focus of development and planning towards enhancement of human well-being and reduction in inequalities along with growth of per capita income especially targeting vulnerable social groups, viz. STs, SCs, etc. This well-being encompasses individual attainment in the areas of education, employment, health care, nutritional level and amenities like electricity, water supply, sanitation, housing, etc. It explores certain aspects of their livelihoods which are commonly neglected. The sustainable livelihood proceed towards enable government departments and Ngo's to upgrade the design and implementation of poverty alleviation programmes and projects in tribal areas. It helps to examine advantages and constraints of the tribal poor, builds better understanding 
of multiple perspectives, identifies which options have better potential to minimize poverty and what available conditions, policies and incentives are needed for the poor to increase the extent of better livelihood options. For high well-being, more income, reduced vulnerability, increased food security with more sustainable use of the natural resource base, the sustainable livelihoods are to be identified, documented, analysed, improved, customised, and created for tribal communities.

Income generation is the key constituent of livelihood for better living which enables the tribal farmers to lead sustainable livelihood.

\section{Materials and Methods}

For this study, ex-post facto research design was adopted. According to Kerlinger (1968), ex-post facto research is a systematic empirical enquiry, in which the scientists do not have direct control on influencing variables because their manifestations have already occurred. Influence about relation among variables is made without direct intervention. Sampling is the method of selecting a fraction of the population in such a way that the selected sample represents the population. For selection sample for the study, four stage sampling method namely selection of district, selection of talukas, selection of villages and selection of respondents was allowed.

Nanded district of Maharashtra was purposively selected for the study as, Nanded district has a population of about 2,81,695 scheduled tribes and this district is ranked $1^{\text {st }}$ in scheduled tribes population in the Marathwada region, and ranked $15^{\text {th }}$ in Maharashtra state (Directorate of Census Operations, Maharashtra, 2013). Nanded district having 16 talukas and all are having considerable tribal population, Kinwat,
Hadgaon and Bhokar talukas are having highest tribal population. Kinwat and Bhokar talukas are randomly selected. Six villages from each of the two talukas were selected by following simple random sampling method, thus making total of twelve villages. From each of the selected village ten (10) respondents were selected by following random sampling procedure, thus making a total of 120 respondents.

The variables selected were- age, education, farm size, farming experience, training received, risk orientation, religious belief, achievement motivation, extension contact, mass media exposure, ethnocentrism and income generation. The interview schedule was developed and they were given code numbers for identification. The respondents were requested to response verbally to all the questions. The analysis of data was carried out by using scoring, correlation, null hypothesis and empirical hypothesis.

To find out association between income generation and socio economic profile of the tribal farmers.

\section{Results and Discussion}

Association between income generation and socio economic profile of the tribal farmers with respect to their sustainable livelihoods

In order to study the relationship between the income generation of tribal farmers from sustainable livelihoods and their profile characteristics, the correlation co-efficient (r) values were computed and findings are furnished here under.

The relationship between the income generation of tribal farmers from sustainable livelihoods and their profile characteristics was tested by relevant null and empirical hypotheses. 
Association between age and income generation

From the table 1 and figure 1 the findings it was evident that a negative and significant correlation exists between age and income generation. This may be due to the fact that most of the respondents were of middle to young age and were more interested in government wage employment works under MGNREGA and other schemes as compared to working in their fields due to the nature of work, convenience, easy earning, secured income. The development agencies should create awareness and interest about diversified income generating activities among the tribal community to increase their income generation capacity. These findings are in accordance with the results of Chandrasekher (1995) and Mahesh (2016).

\section{Association between education and income generation}

It was evident from the table 1 and figure 1 that education had no significant effect on the dependent variable income generation. These findings are in accordance with the results of Chandrasekher (1995), Prajapati et al., (2014) and Mahesh (2016).

\section{Association between farm size and income generation}

From the table 1 and figure 1 the findings it was apparent that a positive and significant correlation exists between farm size and income generation income generation might be increased with increase in the farm size due to the possibility of additional components, resulting in increased income. The development agencies should come up with suitable Integrated Farming System approach for increase in the farming intensity and income generation. These findings are in accordance with the results of Chandrasekher (1995) and Mahesh (2016).
Association between farming experience and income generation

From the table 1 and figure 1 , the variable farming experience had negative and significant correlation with income generation. The reason behind the negative trend may be due to the fact that the middle aged and young tribal farmers were more involved in relatively new technologies as compared to their older counterparts, who were still engaged in the old and traditional agricultural practices.

The government should take initiatives to identify the innovative ones among the group for diffusion of the new and suitable practices in the study area for better income generation among the tribal farmers. These findings are in accordance with the results of Mahesh (2016).

Association between training received and income generation

From the table 1 and figure 1 the variable training received showed positive and significant correlation with income generation.

As with higher level of knowledge and skills through training, correspondingly there would be enough chances for improvement in income generation too.

Therefore target groups should be identified and imparted technical as well as entrepreneurial skills to enhance their income generation capacity. These findings are in accordance with the results of Mahesh (2016).

\section{Association between risk orientation and} income generation

From the table 1 and figure 1 findings of the investigation showed a non-significant relation between risk orientation and income generation, which means risk orientation had no significant effect on income generation. 
Probable reason for this might be that the tribal farmers believe in fate philosophy, they may not take risk adopting new technologies irrespective of its income generation potential. These findings are in accordance with the results of Mahesh (2016).

Association between religion belief and income generation

From the table 1 and figure 1 religious belief had negative and non-significant correlation with income generation. Which means income generation was not affected by the level of religious belief of the tribal farmers. These findings are in accordance with the results of Ratnakar (1990) and Mahesh (2016).

\section{Association between achievement motivation and income generation}

motivation had a positive and significant correlation with income generation, means if the person is motivated to achieve will have better income generation.

It was observed that although the respondents had medium achievement motivation, when it comes to certain livelihood activities of their taste like MGNREG, short duration crops, beedi leaf collection, seasonal NTFP collection, which involves less investment and immediate income, they showed relatively high achievement motivation. So, if certain livelihood measures of their acceptance are identified and promoted, their overall achievement motivation could be improved, ultimately resulting in better income generation. These findings are in accordance with the results of Dhanasree et al., (2014) and Mahesh (2016).

From the table 1 and figure 1 achievement

Table.1 Association between income generation and socio economic profile of the tribal farmers with respect to their sustainable livelihoods

\begin{tabular}{|c|c|c|}
\hline Sr. No. & Characteristics & Correlation coefficient (r) \\
\hline $\mathbf{1}$ & Age & $-0.243^{*}$ \\
\hline $\mathbf{2}$ & Education & $0.121^{\mathrm{NS}}$ \\
\hline $\mathbf{3}$ & Farm size & $0.234^{*}$ \\
\hline $\mathbf{4}$ & Farming Experience & $-0.239^{*}$ \\
\hline $\mathbf{5}$ & Training received & $0.199^{*}$ \\
\hline $\mathbf{6}$ & Risk orientation & $0.170^{\mathrm{NS}}$ \\
\hline $\mathbf{7}$ & Religion belief & $-0.133^{\mathrm{NS}}$ \\
\hline $\mathbf{8}$ & Achievement motivation & $0.313^{* *}$ \\
\hline $\mathbf{9}$ & Extension contact & $0.233^{*}$ \\
\hline $\mathbf{1 0}$ & Mass media exposure & $0.353^{* *}$ \\
\hline $\mathbf{1 1}$ & Ethnocentrism & $-0.230^{*}$ \\
\hline
\end{tabular}

* Significant at 0.05 level of probability

** Significant at 0.01 level of probability

NS -Non Significant 
Fig.1 Association between income generation and socio economic profile of the tribal farmers with respect to their sustainable livelihoods

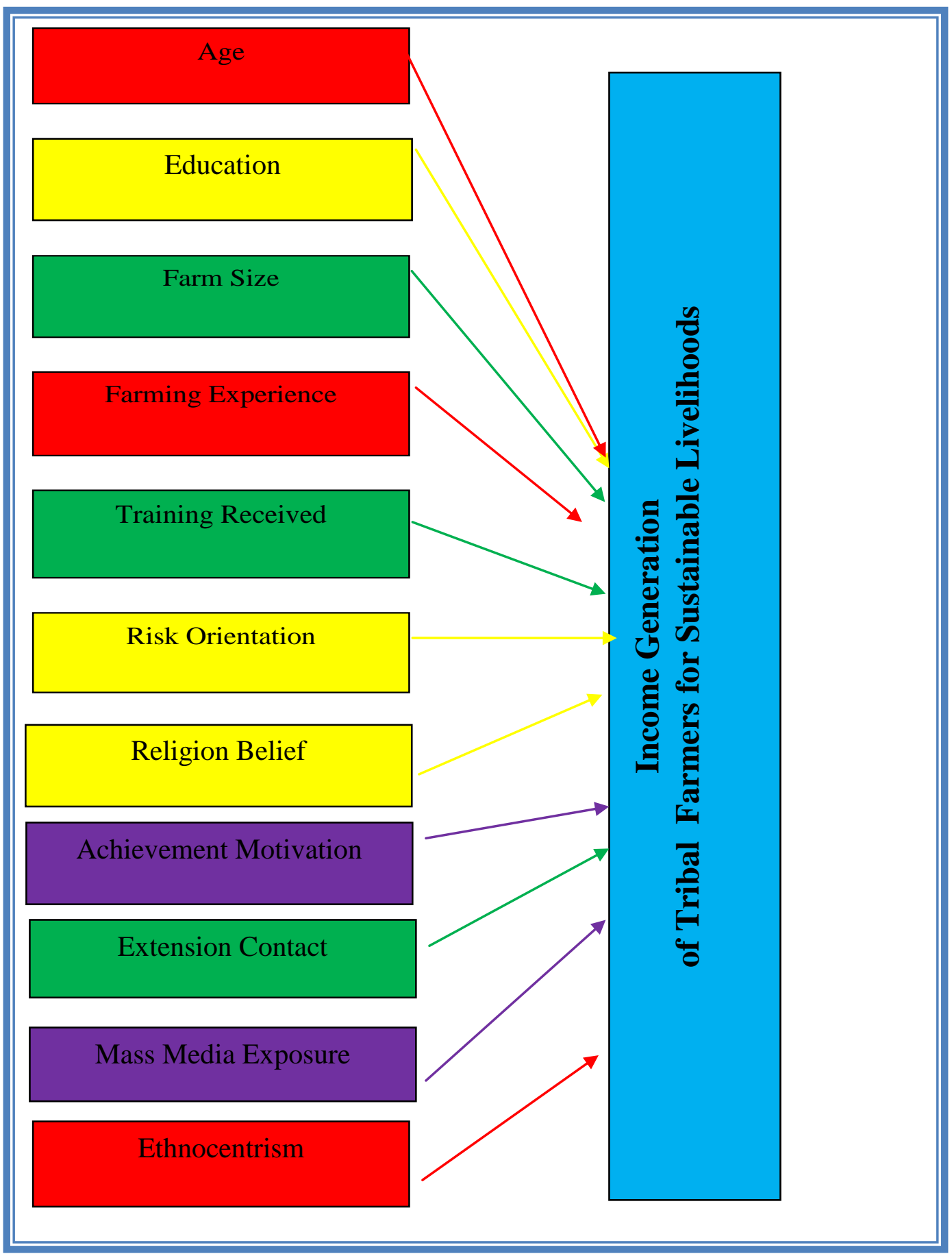

$\longrightarrow$ Negatively significant at 0.01 and 0.05 level of probability.

No Significant

$\longrightarrow$ Significant at 0.05 level of probability

$\longrightarrow$ Significant at 0.01 level of probability 
Association between extension contact and income generation

From the table 1 and figure 1 extension contact had positive and significant correlation with income generation. It may be attributed to the fact that with the increase in contact with extension activities and extension personnel, there may be more chances of getting better quality seeds or inputs from govt officials on subsidy basis and by that they can reduce cost of livelihood practices and can result in better income generation. As mentioned earlier, the government should try to ensure sufficient staff strength in the agencies involved in extension in order to reach the unreached.

These findings are in accordance with the results of Ratnakar (1990) Chandrasekher (1995) Dhanasree et al., (2014) and Mahesh (2016).

\section{Association between mass media exposure and income generation}

From the table 1 and figure 1 mass media exposure had positive and significant correlation with income generation. This trend may be due to the fact that with sufficient exposure to mass media tools like, T.V, radio, kisan melas, ICT's, news paper and agricultural magazines, tribal people can know better about market prices and new income generation activities.

To increase mass media exposure government should conduct more kisan melas, target based television shows and strengthening of ICT tools can also provide good platform for improved mass media exposure among the tribal farmers. Community radio can also be a good initiative for the study area, which can cater the need for information in local languages. These findings are in accordance with the results of Chandrasekher (1995 and Mahesh (2016).
It is revealed from the study that, calculated ' $r$ ' values between age, farm size, farming experience, training received, extension contact, ethnocentrism and the income generation of sustainable livelihoods were greater than table ' $r$ ' value at 0.05 level of probability, whereas, the calculated ' $r$ ' value of the variables achievement motivation and mass media exposure were greater than table ' $r$ ' value at 0.01 level of probability.

Therefore, it can be concluded that there was a positive and significant relationship between income generation of sustainable livelihoods of farmers and the variables farm size, training received, achievement motivation, extension contact and mass media exposure.

Calculated ' $r$ ' values between age, farming experience ethnocentrism and the income generation of sustainable livelihoods of farmers have negative and significant relationship. On the other hand education, risk orientation and, religious belief has no significant relationship with the income generation of sustainable livelihoods of tribal farmers.

\section{Acknowledgement}

The authors are thankful to Department of Extension Education, College of Agriculture, Parbhani; VNMKV, Parbhani. (M. S.)-431402 for providing all facilities required during experimental work.

\section{References}

Chandrasekher, S. 1995. A study on the effectiveness of selected agricultural programmes of ITDA on tribal farmers in Adilabad district of Andhra Pradesh. M.Sc. (Ag.) Thesis. Andhra Pradesh Agricultural University, Rajendranagar, Hyderabad.

Dhanasree, K., Vijayabhinandana, B and Pradeepkumar, P.B. 2014. Socio- 
economic empowerment of tribal women in high altitude and tribal zone of Andhra Pradesh. International Journal of Innovative Research in Science, Engineering and Technology, 3(2): 9360-9368.

Kerlinger, N.F. 1968. Foundations of Behavioural Research. Surjeet Publications. New Delhi.

Mahesh, L. 2016. A Study on Sustainable Livelihoods of Tribal Farmers Of Adilabad District of Telangana State. M.Sc. (Ag.) Thesis. Professor Jayashankar Telangana State
Agricultural

Rajendranagar, Hyderabad.

Prajapati,M., Solanki, K.D., Patel R And Dhandhukia R. 2014. Measurement of the existing sustainable livelihood of the tribal and non-tribal farmers. Advance Research in Agriculture And Veterinary Science. Vol. (1) 2: 83-87

Ratnakar, R. 1990. Study on impact of ITDA on the tribal farmers of Khammam district of Andhra Pradesh. Ph.D Thesis. Andhra Pradesh Agricultural University, Hyderabad, India.

\section{How to cite this article:}

Gogi Reddy, V.K., J.V. Ekale, M.V. Kulakarni and Nair, R.G. 2019. Association between Income Generation and Socio Economic Profile of the Tribal Farmers of Nanded District, India. Int.J.Curr.Microbiol.App.Sci. 8(11): 2508-2514. doi: https://doi.org/10.20546/ijcmas.2019.811.289 